Malvik, T.O., Engebø, A., Wondimu, P.A., Johansen, A., and Kalsaas, B.T. 2020. "Comparing Road Construction Projects Against an IPD Standard." In: Tommelein, I.D. and Daniel, E. (eds.). Proc. $28^{\text {th }}$ Annual Conference of the International Group for Lean Construction (IGLC28), Berkeley, CA, USA, doi.org/10.24928/2020/0086, online at iglc.net.

\title{
COMPARING ROAD CONSTRUCTION PROJECTS AGAINST AN IPD STANDARD
}

\author{
Tobias O. Malvik ${ }^{1}$, Atle Engebo ${ }^{2}$, Paulos A. Wondimu ${ }^{3}$, \\ Agnar Johansen ${ }^{4}$, and Bo Terje Kalsaas ${ }^{5}$
}

\begin{abstract}
As a way of improving project performance, collaborative project delivery methods (PDMs) have been presented as a potential solution. Integrated Project Delivery (IPD) is a relational PDM that has gained a lot of attention in recent years. However, laws, regulations and internal restrictions are factors that limit a project's influence on its PDM, and implementing IPD is not always possible. In this study, we address three large road construction projects with different approaches to a collaborative PDM. In the paper, we ask "How can projects use alternative organization and contract arrangements to achieve incentives which resemble the IPD arrangement?" The study was carried out by conducting a literature study and a case study approach. Three projects were investigated via document reviews and semi-structured interviews with key actors in the value chains. We conclude that there are several possible ways to arrange a relational PDM to facilitate efficient project execution. The level of collaboration, the timing of contractor involvement and the structure of the contract and procurement procedure are examples of adjustable factors in early stages that affect project execution.
\end{abstract}

\section{KEYWORDS}

Lean Construction, Public-Private Partnership, Relational Project Delivery Methods, Integrated Project Delivery

\section{INTRODUCTION}

Projects are developed to create value for the owner and other stakeholders. The degree to which they succeed in doing so is variable (Merrow 2011; Oliveira and De Muylder 2012; Kerzner 2017). One emphasis in the literature views project performance as a governance challenge, looking at it from the owner's perspective (Morris 2013; Hjelmbrekke et al. 2014; Klakegg 2015; Muller 2017). Another direction in the literature sees project performance as a management challenge and applies the project management's perspective (Shenhar and Dvir 2007; Andersen 2010). The choice of an

1 Research Assistant, NTNU - Norwegian University of Science and Technology, Trondheim, Norway, +47 98670 354, tobias.o.malvik@ntnu.no, orcid.org/0000-0002-7588-1899

2 PhD Candidate, NTNU - Norwegian University of Science and Technology, Trondheim, Norway, atle.engebo@,ntnu.no, orcid.org/0000-0002-5293-0176

$3 \mathrm{PhD}$, Norwegian Public Roads Administration (NPRA), paulos.wondimu@vegvesen.no, orcid.org/0000-0001-9421-594X

4 Professor, Dr philos, NTNU - Norwegian University of Science and Technology, Trondheim, Norway, a.johansen@,ntnu.no, orcid.org/0000-0003-0063-3679

5 Professor, Dr. Ing., University of Agder, Grimstad, Norway, bo.t.kalsaas@uia.no, orcid.org/0000-0003$\underline{4383-1683}$ 
optimal project delivery method (PDM) is an important strategic governance decision (Klakegg 2017). PDMs are complex matters. It is important to determine whether it is best in the long run to design a specific model adapted to the special features of each project and in light of current trends and the market situation, or to specialize in one specific model and standardize as far as possible. Every project has a definitive start and end and is usually divided into phases or stages that follow a logical sequence. The phases are determined by governance and control requirements and are collectively known as the project life cycle.

Integrated Project Delivery (IPD) is a project delivery model that has attracted significant interest in the Lean Construction community (Lichtig 2005; Matthews and Howell 2005). The development of the IPD contractual framework can be seen as an effort to meet the lean construction principles formulated in the five "big ideas," summarized as 1) collaboration, 2) relationships, 3) a network of commitments, 4) optimization and 5) the pairing of learning with action (Lichtig 2005). IPD can also be conceived as a development to get around the limitations found in DBB and DB regarding the alignment of interests in construction projects. The American Institute of Architects (AIA) (2014) identifies IPD principles as continuous involvement of the owner, key designers and contractors from early design through to project completion; shared risk and reward; joint project control; limited liability; and multi-party agreement or equal interlocking agreements.

The theoretical foundation of aligning interests lies within the lean construction (LC) triangle (Thomsen et al. 2009a; Howell 2011; Ballard 2012). The LC triangle looks at the importance of fine-tuning the parties concerning contractual commercial incentives to achieve a project organization founded on common interests and collaboration across parties, which is a framework for value creation in design and production.

In this paper, we are studying and comparing three projects by using a qualitative case study approach. The three projects have not used IPD contracts but have established variations of relational contract arrangements in road construction that have many similarities to the IPD concept. The goal of these variations was to achieve a similar effect when it comes to alignment of interests and collaboration. Hence, our research question is "How can projects use alternative organization and contract arrangements to achieve incentives which resemble the IPD arrangement?"

\section{GENERALIZATION OF PROJECT DELIVERY METHODS}

A PDM can be defined as "a system for organizing and financing design, construction, operations, and maintenance activities that facilitates the delivery of goods or services" (Miller et al. 2000). It includes the choice of a decision-making structure, tendering process, contract formats, etc. Klakegg (2017) presents nine main elements of a PDM. The PDM is the totality of these elements as an integrated whole. The art is in putting them together in a way that provides optimal conditions for success. The nine elements are:

1. Organization form - the choice of how the principal structures should be designed to secure efficient decision making and project governance.

2. Form of specification - the choice of how deliverables should be described as a basis for procurement and how performance should be defined and measured.

3. Work Breakdown Structure - the task is broken down into manageable pieces for control. 
4. Contract structure - the choice of how the scope is divided into work packages fit for contracts.

5. Procurement route - the choice of how to recruit the best resources to the project, securing the right suppliers to match the needs of the project.

6. Contract format - The choice of what contract format to use in the project; i.e., standardized or specially fitted, transactional or relational, etc.

7. Conflict resolution form - how to secure effective conflict resolution when parties do not see eye to eye.

8. Risk-sharing format - how the contract is designed concerning the sharing of risk and opportunities.

9. Price format - the choice of what payment is going to be triggered by specific deliveries or services; i.e., fixed price, unit prices, or sharing models.

Morris (2002) indicates that the one thing that distinguishes projects from non-projects is that all projects, no matter how complex or trivial, go through a common life-cycle development sequence. He defines the project life cycle as "the sequence of phases through which the project will evolve." The generic project life cycle model is presented in Figure 1.

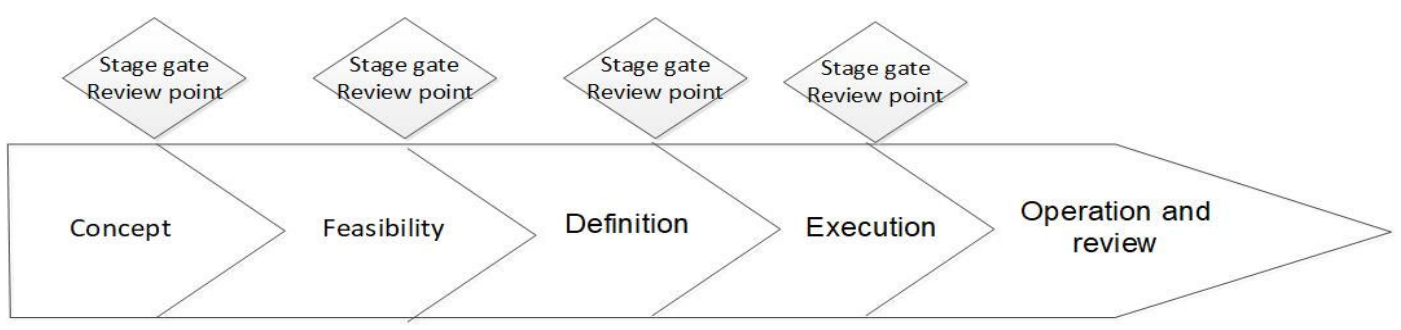

Figure 1: Project life cycle (adapted from Morris (2002))

\section{LEAN LITERATURE ON PROJECT DELIVERY METHODS}

The lean community often refers to project delivery methods as delivery systems, and the Lean Construction Institute (LCI) explains the concept into "physics of work," "systems and organizations" and "contracts" (Lichtig 2005). This latter created the foundation for the specific method called Integrated Project Delivery (IPD), which is the lean take on relational-based project delivery. Already in 2003 was it acknowledged in the lean literature that maximizing value and minimizing waste is difficult when the contractual structure inhibits coordination, cooperation and innovation and rewards individual actors for both reserving good ideas and optimizing their performance at the expense of others (Matthews et al. 2003). The latter paper has focused on other aspects concerning lean delivery systems. Heidemann and Gehbauer (2010) identified some factors required for succeeding when using a relational-based project delivery method in the context of lean. Fundamentally, modifications should be made to procurement rules, selection criteria and commercial terms. Another key issue highlighted is how the project delivery method affects value. By comparing CM-at-Risk (CMR) and Competitive Sealed Proposal (CSP), Kulkarni et al. (2012) found that relational-based project delivery produces a more reliable cost outcome for public owners. Following the same track, Alarcón et al. (2013) sought to provide an understanding on how Lean Project Delivery distinguishes from "traditional practice," concluding that integrated teams, early involvement, organizational 
structure, Last Planner ${ }^{\circledR}$ System, operational systems, relational contracts, type of contract or commercial terms are all key characteristics of IPD.

A central challenge regarding relational-based project delivery is that it suffers from its indistinct take on collaboration and distinction between 'collaboration,' 'cooperation' and 'coordination' (Melo et al. 2013). On a practical level, the effects of early contractor involvement have positive implications, including improved cost estimation, planning, constructability, and risk management, but also a reduced number of errors and changes in later phases (Sødal et al. 2014). Changing from traditional to new ways of doing things is not necessarily easy and not all individuals or firms are prepared for this transformation. Project managers need appropriate education, teaching, and training.

Collaboration and how to promote collaboration in design have been studied extensively. Lean tools and methods include co-location, 'Big Room,' Last Planner ${ }^{\circledR}$ System, cross-functional teams, Choosing By Advantages, Value Stream Mapping, use of an A3 report and building information modeling for boundary-crossing (Pikas et al. 2016; Mesa et al. 2019; Kalsaas 2020). Thomsen et al. (2009b) argue that all PDMs consist of three basic domains: the project organization, the projects "operating system" and the commercial terms (contract) binding the project participants. These three domains form the lean construction triangle. To bridge theory and empirical evidence, we elaborate on the dimensions of the LC-triangle. To analyze what elements that have positive or negative impact on collaboration/integration. When it comes to contract, we address issues such as if a multi-party contract with shared risk and opportunities have been used; if target or fixed price have been used or open or closed book. Regarding organization, it is central to look for wether early involvement of contractors have been utilized. For the operating system we address if the studied projects apply target value design (TVD), process-oriented planning and production control (Last Planner ${ }^{\circledR} /$ Virtual Design in Construction). Moreover, how has learning and continuous improvement been addressed and has there been a co-location of the key actors on-site.

\section{METHOD AND RESEARCH DESIGN}

To answer the research question, a case study was conducted together with an analysis of relevant literature. The study has a descriptive and adaptive starting point (Tjora 2012). The abductive research approach has its starting point in the theory, while acknowledging the importance of theory and perspective in the beginning of the inquiry and during the research process. According to Dubois and Gadde (2002), the abductive approach is about investigating the relationship between 'everyday language and concepts,' which is similar to induction. An abductive approach iterate between the inductive and deductive approaches. A deductive research approach starts with theory or models and uses them to analyze and understand a specific problem or idea. Consequently, a qualative research approach is normally preferred. Deductive research moves from general ideas or theories to specific, particular situations: the particular is deduced from the general, such as broad theories (Neville 2004; Tjora 2012).

This literature review was carried out by following the procedures described by Blumberg et al. (2014) to assure an in-depth knowledge of studied concepts. 
Table 1: Case study: project information and data sources

\begin{tabular}{|l|l|l|l|}
\hline & $\begin{array}{l}\text { Project 1 } \\
\text { Rv. 3 Løten-Elverum }\end{array}$ & $\begin{array}{l}\text { Project 2 } \\
\text { E6 Ulsberg-Vindåsliene }\end{array}$ & $\begin{array}{l}\text { Project 3 } \\
\text { E6 Mandal East-City }\end{array}$ \\
\hline $\begin{array}{l}\text { PDM and } \\
\text { procurement } \\
\text { procedure }\end{array}$ & $\begin{array}{l}\text { Tender with negotiation, } \\
\text { PPP }\end{array}$ & $\begin{array}{l}\text { BVP, Partnering and DB } \\
\text { with target price }\end{array}$ & $\begin{array}{l}\text { BVP, Collaborative } \\
\text { design and DB with } \\
\text { fixed price }\end{array}$ \\
\hline $\begin{array}{l}\text { Current stage in } \\
\text { the project LC }\end{array}$ & Late execution & Zoning plan & Early execution \\
\hline $\begin{array}{l}\text { Semi structured } \\
\text { interviews }\end{array}$ & 5 & 8 & 11 \\
\hline Document study & $\begin{array}{l}\text { Contract Procurement } \\
\text { doc. } \\
\text { Description of PDM }\end{array}$ & $\begin{array}{l}\text { Contract Procurement doc. } \\
\text { Description of PDM }\end{array}$ & $\begin{array}{l}\text { Contract Procurement } \\
\text { doc. } \\
\text { Description of PDM }\end{array}$ \\
\hline
\end{tabular}

Three infrastructure projects were investigated through $(5+8+11)$ semi-structured, indepth, case-specific interviews with key actors (from the client, contractor, and engineering designer) following the methodological approach described by Yin (2009). Each interview was conducted at the interviewee's office with the use of an interview guide that was established based on the research question. A document study (contracts, procurement strategies, description of PDMs, etc.) was performed on all case projects as part of the data gathering process. All interviewees were key personnel in the studied projects. Including both contractor and developer respondents assured balance in the interview findings. In case 1, a 6-hour group interview was carried out, with two participants from the client and one from the developer/contractor. Three single 1-1.5 hour interviews were carried out by use of video. In case 2, eight single 1-1.5 hour interviews were carried out- four out of these was done by video. Case 3 consisted of eleven single 1-1.5 hour interviews, two out of them was done by video. To increase data collection reliability, each interview was summarized during the interview process by two scientists on an interview team. Both researchers made separate notes from the interview, and both conducted coding after the interview in "themes" individually. Interpreting the meaning of themes, descriptions were done in a joint meeting with the entire research team.

However, some limitations are still present in this research. First, this paper only investigated three Norwegian large infrastructure projects. Second, representation was not the same from clients and contractors, and only two of the cases included representatives from engineering designers.

\section{CASE STUDIES FINDINGS AND DISCUSSION}

In 2016, the Norwegian Government founded Nye Veier (translates to "New Roads") as a new wholly state-owned road infrastructure organization. Nye Veier was founded to compete with the Norwegian Public Roads Administration (NPRA), which until 2016 was responsible for all planning and building of major infrastructure projects in Norway. The idea with the creation of Nye Veier was to establish a lean, efficient and specialized organization that used different delivery models to build cheaper roads more quickly (Nye Veier 2020).

This study examines three different road infrastructure projects in Norway, all with motivation to collaborate but with different approaches to accomplish collaboration. Table 2 (Malvik and Johansen 2020) summarizes how the projects achieved the elements 
an IPD approach aims to promote, with a foundation in principles promoted by the American Institute of Architects (AIA).

Table 2: AIA principles in the three projects

\begin{tabular}{|c|c|c|c|c|c|c|}
\hline \multirow[t]{2}{*}{$\begin{array}{c}\text { AIA } \\
\text { principles }\end{array}$} & \multicolumn{2}{|c|}{$\begin{array}{c}\text { Project } 1 \\
\text { Loten-Elverum }\end{array}$} & \multicolumn{2}{|c|}{$\begin{array}{c}\text { Project } 2 \\
\text { Ulsberg-Vindåsliene }\end{array}$} & \multicolumn{2}{|c|}{$\begin{array}{c}\text { Project 3 } \\
\text { Mandal East-City }\end{array}$} \\
\hline & $\begin{array}{l}\text { Optimization } \\
\text { phase }\end{array}$ & $\begin{array}{l}\text { Execution } \\
\text { phase }\end{array}$ & $\begin{array}{l}\text { Optimization } \\
\text { phase }\end{array}$ & $\begin{array}{l}\text { Execution } \\
\text { phase }\end{array}$ & $\begin{array}{l}\text { Optimization } \\
\text { phase }\end{array}$ & $\begin{array}{l}\text { Execution } \\
\text { phase }\end{array}$ \\
\hline $\begin{array}{l}\text { Continuous } \\
\text { involvement } \\
\text { of the } \\
\text { owner }\end{array}$ & $\begin{array}{l}\text { Yes, part of } \\
\text { the } \\
\text { negotiation } \\
\text { process }\end{array}$ & $\begin{array}{l}\text { Yes, in a } \\
\text { distanced } \\
\text { way. } \\
\text { Involved in } \\
\text { change of } \\
\text { scope }\end{array}$ & $\begin{array}{l}\text { Yes, in } \\
\text { developing } \\
\text { the target } \\
\text { price }\end{array}$ & $\begin{array}{l}\text { Not } \\
\text { available, but } \\
\text { intentional }\end{array}$ & $\begin{array}{l}\text { Yes, in } \\
\text { developing } \\
\text { the target } \\
\text { price }\end{array}$ & $\begin{array}{l}\text { No, DB with } \\
\text { fixed price. }\end{array}$ \\
\hline $\begin{array}{l}\text { Key } \\
\text { designers, } \\
\text { contractors } \\
\text { from design } \\
\text { through } \\
\text { project } \\
\text { completion }\end{array}$ & $\begin{array}{l}\text { No, they } \\
\text { were } \\
\text { involved } \\
\text { from detailed } \\
\text { planning }\end{array}$ & Yes & $\begin{array}{l}\text { Yes, } \\
\text { significant } \\
\text { rezoning }\end{array}$ & $\begin{array}{l}\text { Not } \\
\text { available, but } \\
\text { intentional }\end{array}$ & $\begin{array}{l}\text { Yes, they } \\
\text { were } \\
\text { involved } \\
\text { from zoning } \\
\text { planning } \\
\text { phase }\end{array}$ & $\begin{array}{l}\text { Yes, in the } \\
\text { detailed } \\
\text { design }\end{array}$ \\
\hline $\begin{array}{l}\text { Shared risk } \\
\text { and reward }\end{array}$ & No & $\begin{array}{l}\text { Yes, part of } \\
\text { the } \\
\text { discussion in } \\
\text { the execution } \\
\text { phase }\end{array}$ & $\begin{array}{l}\text { Yes, open } \\
\text { book and } \\
\text { target price }\end{array}$ & $\begin{array}{l}\text { Not } \\
\text { available, but } \\
\text { intentional }\end{array}$ & $\begin{array}{l}\text { Yes, open } \\
\text { book and } \\
\text { target price }\end{array}$ & $\begin{array}{l}\text { No, DB with } \\
\text { fixed price }\end{array}$ \\
\hline $\begin{array}{l}\text { Joint } \\
\text { project } \\
\text { control }\end{array}$ & $\begin{array}{l}\text { No, client in } \\
\text { the control }\end{array}$ & $\begin{array}{l}\text { No, } \\
\text { contractor in } \\
\text { control }\end{array}$ & $\begin{array}{l}\text { Yes, but the } \\
\text { engineering } \\
\text { company in } \\
\text { the lead }\end{array}$ & $\begin{array}{l}\text { Not } \\
\text { available, but } \\
\text { intentional }\end{array}$ & $\begin{array}{l}\text { Yes, but the } \\
\text { engineering } \\
\text { company in } \\
\text { the lead }\end{array}$ & $\begin{array}{l}\text { No, DB with } \\
\text { fixed price }\end{array}$ \\
\hline $\begin{array}{l}\text { Limited } \\
\text { liability }\end{array}$ & No & $\begin{array}{l}\text { Partly. Client } \\
\text { pays for } \\
\text { access to the } \\
\text { road when } \\
\text { delivered }\end{array}$ & $\begin{array}{l}\text { No, but the } \\
\text { agreement is } \\
\text { believed to } \\
\text { create strong } \\
\text { bond } \\
\text { between } \\
\text { main actors }\end{array}$ & $\begin{array}{l}\text { Not } \\
\text { available, but } \\
\text { not } \\
\text { intentional }\end{array}$ & $\begin{array}{l}\text { No, but they } \\
\text { have a } \\
\text { conflict } \\
\text { management } \\
\text { system } \\
\text { denoted } \\
\text { alliance } \\
\text { group }\end{array}$ & $\begin{array}{l}\text { No, DB with } \\
\text { fixed price }\end{array}$ \\
\hline $\begin{array}{l}\text { Multi-party } \\
\text { agreement } \\
\text { or equal } \\
\text { interlocking } \\
\text { agreements }\end{array}$ & No & $\begin{array}{l}\text { No, two-part } \\
\text { agreement }\end{array}$ & $\begin{array}{l}\text { No, } \\
\text { designers } \\
\text { hired by the } \\
\text { contractor. } \\
\text { No bonus for } \\
\text { designers }\end{array}$ & $\begin{array}{l}\text { Not } \\
\text { available, but } \\
\text { not } \\
\text { intentional }\end{array}$ & $\begin{array}{l}\text { No, but the } \\
\text { designers are } \\
\text { eligble to } \\
\text { bonus from } \\
\text { the } \\
\text { contractor }\end{array}$ & No \\
\hline
\end{tabular}

NPRA has traditionally used Design-Bid-Build (DBB) contracts but is now steadily increasing the amount of Design-Build (DB) contracts. Nye Veier has decided to specialize in collaborative DB contracts and adds PDM elements such as Best Value Procurement (BVP), operation contracts for the road after construction, and a fully digital execution strategy (Klakegg 2017).

The increased competition with Nye Veier seems to have spurred innovative thinking in the road infrastructure segment, which has led to a great variety of PDMs. One example is the comeback of the Public-Private Partnership (PPP). PPPs have not been used in road infrastructure for the last 10-15 years in Norway but are now being implemented again in major projects by NPRA. Based on the earlier-described project life cycle, project delivery methods for cases 1, 2, and 3 from NPRA and Nye Veier are presented in Figure 2 . 


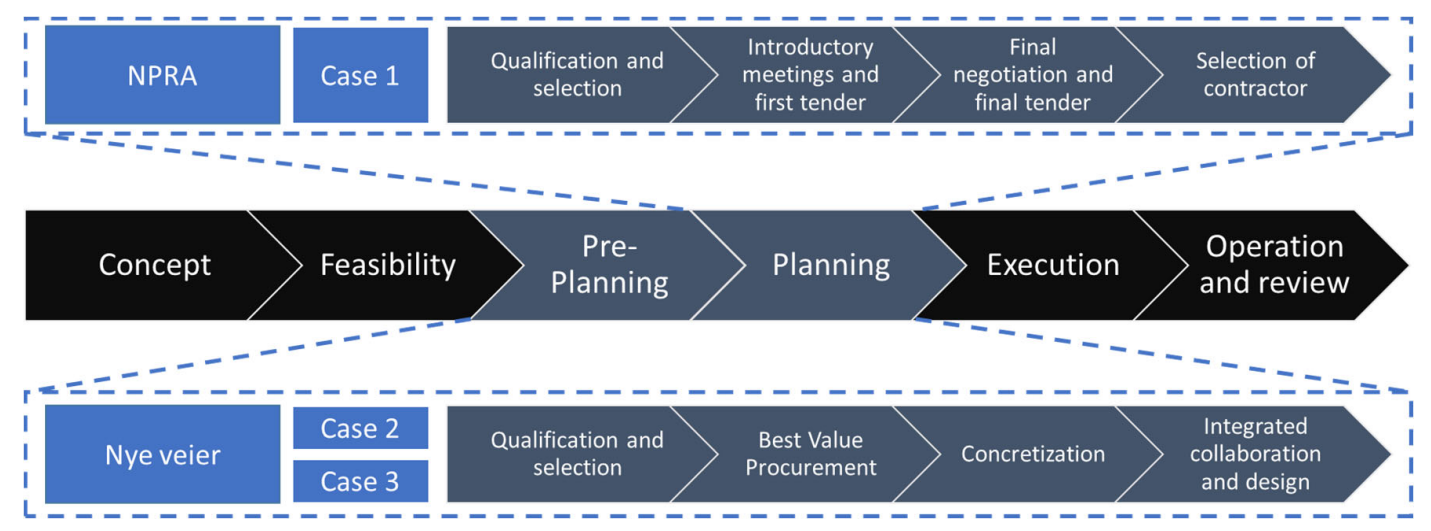

Figure 2: Tendering process and collaboration before execution in the three projects

\section{NPRA RV. 3 - Public-Private Partnership}

The Norwegian Government recognizes the benefits of PPP, so the Ministry of Transport and Communications has asked NPRA to carry out more PPP projects. There are now three new major PPP projects established by NPRA, with a combined expected investment of \$2.2 Bn. This is how NPRA defines PPP (Statens Vegvesen 2020):

"Under the Public-Private Partnership (PPP) model, a private company is given full responsibility for a road section for a period of 20-30 years. The company is responsible for financing, design, development, operation, and maintenance. The company's task is to make sure that the road is open and available for public travel and that it conforms to the agreed standard."

This study investigated one of the three ongoing Norwegian PPP projects, Rv. 3 (Norwegian highway 3) Løten - Elverum. The contract was announced early in 2017 and has an estimated worth of $\$ 550 \mathrm{M}$, which makes the project one of the largest road infrastructure projects in Norway. The road section between Elverum and Løten is a part of the fastest road access for cars between Oslo and Trondheim and is considered to be an important road section for the transport of goods between two of Norway's largest cities. Twenty-five $\mathrm{km}$ of this road is to be upgraded and built, and the project is expected to be open for traffic during the summer of 2020. The contractor on the project founded a PPP company solely for this project, and the company is responsible for the construction, operation and maintenance of the road for 20 years, as well as for financing the project during the construction period. The contractor will be paid when the project is delivered. Since the contractor is financing the project, there is good motivation to finish the work quickly and ahead of the time specified in the contract. However, the contractor is also responsible for operation and maintenance, which provides incentive to choose solutions with higher quality and lower lifetime cost rather than solutions solely based on low cost or quick implementation.

The procurement procedure of the project was tender with negotiation. This procedure was performed between the zoning and execution phases and took approximately one year to complete. The procedure started with a qualification round, where the number of contractors was scaled down to the three best contractors, who then became eligible to present the first tender. After this stage, introductory meetings were held between the contractors and NPRA before the first tender was presented. The contractors were given five months to prepare the first tender. After the first tender, the contractors had another two months to prepare the second tender, and then an additional two months to prepare 
the third and final tender. Simultaneously with the preparation of the first and second tenders, clarifications and negotiations between the contractors and NPRA were conducted, while final negotiations were completed along with the preparation of the final tender. Each tender was delivered in a sealed envelope, and the contractors had no knowledge or information about their competitors' tenders. After the final tender was delivered, NPRA selected their contractor. This tendering process proved to be valuable for the client. According to one of the project managers from NPRA, the cost difference between the first and final tender was a reduction of $\$ 100 \mathrm{M}$. It can be assumed that this reduction occurred because of the collaboration between NPRA and contractors during the tender process. Also, the difference between two of the final tenders was only $\$ 1.1 \mathrm{M}$, a relatively small difference in a $\$ 550 \mathrm{M}$ contract.

It appears this process achieved a positive impact on the execution phase of the project. According to project managers from both NPRA and the contractor, the collaboration developed during the tendering process assured that the two sides better understood each other and the project objectives. This relationship resulted in a quick startup - 46 excavators were on site one week after start-up; and so far, with approximately $75 \%$ of execution finished, change orders representing only $2 \%$ of contract value have been negotiated. In addition, the project is expecting to deliver 3-4 months earlier than stated in the agreement. Although change orders have been low and the project is delivering as expected, representatives from both NPRA and the contractor maintained that they felt the zoning plan could have been facilitated to give more influence during the execution period. A drawback of this procurement procedure is that it was time-consuming and required many resources from the bidders and the NPRA. Because of this time requirement, both NPRA and the contractor argued that PPP projects with tendering processes like this work best for large projects, with the project at Rv. 3 Løten - Elverum considered to be a minimum in terms of project size. The project manager from the contractor argued that the loser's fee was too low for the participating contractors. The cost of being a part of the tendering process greatly exceeded the loser's fee. The project managers from NPRA, on the other hand, argued that this fee should be as low as possible since this is public money, as long as it was high enough to generate offers from contractors. As table 2 suggests, the PDM used in the project shares few similarities with an IPD approach. However, co-location of client and contractor and negotiation between client and contractor in the procurement phase ensures integration.

\section{NYE VEIER E6 - DESIGN-BUILD WITH A TARGET PRICE}

The PDMs used in Nye Veier's projects are varieties of three different base DB models: a DB contract without zoning plan with a fixed price, a collaborative DB contract with target price, and a collaborative DB contract with fixed price. Nye Veier's project at European Road 6 (E6) Ulsberg - Vindåsliene is using a collaborative Design-Build contract with a target price. The contractor is responsible for the maintenance of the road during a 20 year guarantee period after project completion. The owner's budget is $\$ 255 \mathrm{M}$ for the $25 \mathrm{~km}$ road.If the target price is within the owner's budget, an execution agreement is expected to be signed by September 2020. Since the project still is in the collaborative phase, the results provided from the study of E6 Ulsberg - Vindåsliene will tell more about the motivations behind the choice of execution model and expectations of the project outcome than the final results.

All Nye Veier's project organizations are obliged to apply Best Value Procurement (BVP). One of the project managers in Nye Veier argues that BVP works best when the 
client does not intend to contribute to project management but instead will leave this to the contractor. This approach does not require much time and resources. The project manager from Nye Veier argues that a drawback of the BVP model is that contractors and engineering designers can feel strong ownership of their proposed document, even if it is only partly delivering what the client asked for, leading to a situation where the client must accept solutions they do not necessarily agree with. Contrary to the PPP project, contractors are not involved in a dialogue/negotiation period where they risk losing the contract. However, when there is limited dialogue between the client and the contractor, there is a risk that even the best alternative does not cover what the client initially asked for.

The purpose of using target price is to encourage all parties to look for the best solutions for the project and minimize the contractor's risk to loss of profit. Instead of silo thinking and sub-optimization where each party works for its interest, the project works as a unit to deliver an end product within the limits of the target price. On E6 Ulsberg - Vindåsliene, an "open book" approach was used to decide a target price that was reasonable for both client and contractor.

The main deviation from an IPD model and the PDM in E6 Ulsberg - Vindåsliene is the fact that the engineering designer is not considered to be an equal party with the client and the contractor, and thereby will not share the gain and pain related to the project's overall result. In an IPD, consultants (architects, engineering designers, etc.) would be included as a third equal party, leaving no doubt about their role. A stated value for the E6 Ulsberg - Vindåsliene project is to "optimize the involvement of contract parties in the realization of project objectives."

\section{NYE VEIER E39 - DESIGN-BUILD WITH FIXED PRICE}

E39 Mandal east - Mandal city is Nye Veier's first DB contract that includes a project development phase, which means that the contractor will contribute to the zoning plan process. The contract value is $\$ 175$ million excl. VAT. The detailed zoning plan passed the local government in September 2019, and the construction contract was signed with the main contractor a month later. The project is contracted to be delivered in mid-2022. In the contracting process, BVP was applied to identify the best main contractor.

The client's maximum price (CMP) for the project was set to $\$ 150 \mathrm{M}$ excl. VAT. To be considered for taking part in the final competition, the contractor candidates were required to guarantee that they could deliver the project within CMP before the project development phase took place. After the client had selected the main contractor, the development phase started. The development process lasted 12 months. During this phase, the main contractor and the engineering designers worked together to find and develop an optimal zoning plan within the CMP constraint. This effort was the contractor's responsibility, but the client took part in the collaboration. The aim of the development was not only to address design and lower cost but also optimization related to stakeholders as authorities with responsibilities for the natural environment and external interests. The output of the process was a politically-accepted zonal plan from the local government, which is a detailed and legal document for land use and if necessary, a legal basis for the expropriation of land. The project price that was the output of the project development phase was used to sign a fixed price contract. There was a bonus arrangement in the joint project development process: $50 \%$ sharing of the savings between the contractor and client for possible savings compared to CMP. An open book arrangement was applied to create transparency during the project development phase. At the termination of the 
development process, the parties signed a traditional DB-contract with a fixed sum, which means that the book was closed. At the termination of the project development phase, both the client and the contractor had the option to terminate the contract; however, to do so would incur a significant transaction cost.

In the Mandal project, the CMP was set to $\$ 150 \mathrm{M}$ while the price outcome of the project development phase was $\$ 175 \mathrm{M}$, which included a cost overrun of $\$ 25 \mathrm{M}$. It was obvious that the contractor did not have any commercial incentive to cut the price below CMP, and here it ended up with an increase in the price of $17 \%$. The experience from the project development process indicates that the main contractor made an effort to press the fixed price for the execution phase to be as high as possible. This bid strategy lowered contractor's risk but also had an impact on the bonuses that are awarded if delivered within the new target cost. One of the challenges the contractors experienced in this PDM was that the client did not assign time for the detailed planning phase. As a result, the contractor had to press to find time for this phase, so some of the time designated for the execution phase was used for detailed planning, increasing the risk of late delivery.

\section{CONCLUSION}

This paper set out to answer the research question: "How can projects use alternative organization and contract arrangements to achieve incentives which resemble the IPD arrangement?" by studying and comparing three cases using variations of relational contract arrangements in road construction. More precisely, the discussion is limited to the early phases since the case projects are still ongoing. The in-depth look at the early phase allowed for precise data on ways to arrange a relational project delivery model to achieve an efficient project execution.

NPRA's approach to a relational PDM in the PPP case was a comprehensive tendering process with extensive collaboration with three tenderers. This process seemed to have given them benefits in the relatively straightforward execution phase. The fact that the contractor is responsible for the operation and maintenance of the road for 20 years after completion was an incentive to build a quality road. Another incentive is that faster completion means quicker payment (and fewer expenses) for the contractor.

By using BVP, Nye Veier secures low resource use during the procurement procedure. However, it is harder to determine whether the right contractor is chosen when there is limited dialogue or negotiation with the tenderers. Nye Veier tries to imitate IPD to a larger degree than NPRA, especially at E6 Ulsberg - Vindåsliene. One difference from the PDM in the PPP project is the benefits gained from a more flexible zoning plan, where the contractor is allowed to provide recommendations that are not restricted by zoning regulations. Another difference is that BVP provides tight collaboration with a single contractor and owners do not have to deal with several.

The main difference between the fixed price concept for Mandal East - Mandal city and the target price for Ulsberg - Vindåsliene is that the target price comes with an open book, while fixed price does not. The Mandal-project had an open book in the project development phase. There is a different distribution of risk between fixed price and target price. The contractor takes most of the risk in the fixed price case, whereas he has relatively less risk with target pricing.

\section{REFERENCES}

Alarcón, L.F., Mesa, H., Howell, G. (2013). "Characterization of Lean Project Delivery."

Proc. 21st Ann. Conf. Int. Group for Lean Constr., Fortaleza, Brazil, pp. 247-255. 
American Institute of Architects (2014). "Integrated Project Delivery: An updated working definition." Integrated Project Delivery, American Insitute of Architects (AIA), California Council, 1-18.

Andersen, E.S. (2010). "Rethinking project management-An organisational perspective." Strategic Direction, 26(3), dx.doi.org/10.1108/sd.2010.05626cae.001

Ballard, G. (2012). "Should Project budgets be based on worth or cost." Proc. 20th Ann. Conf. Int. Group for Lean Constr., San Diego, CA, USA, pp. 761-770.

Blumberg, B., Cooper, D. R., Schindler, P.S. (2014). "Business research methods."

Dubois, A., Gadde, L.-E. (2002). "Systematic combining: an abductive approach to case research." Journal of Business Research, 55(7), 553-560.

Heidemann, A., Gehbauer, F. (2010). "Cooperative project delivery in an environment of strict design-bid-build tender regulations." Proc. 8th Ann. Conf. Int. Group for Lean Constr., Haifa, Israel, pp. 581-587.

Hjelmbrekke, H., Lædre, O., Lohne, J. (2014). "The need for a project governance body." International Journal of Managing Projects in Business, 7(4), pp. 661-677.

Howell, G.A. (2011). "Where LCI and DBIA agree and where we differ." Presentation at the January 11, 2011 meeting of DBIA NorCal, Oakland, CA, pp.

Kalsaas, B.T. (2020). "Lean Construction: A management model for interdependencies in detailed design." In: Tzortzopoulos, P., Kagioglon, M. and Koskela, L. (Eds), Lean Construction. Core Concepts and New Frontiers, pp. 209-229, Huddersfield: Routledge.

Kerzner, H. (2017). Project management: a systems approach to planning, scheduling, and controlling. John Wiley \& Sons.

Klakegg, O. J. (2015). "In pursuit of relevance and sustainability." Open Economics and Management Journal, 2(1).

Klakegg, O. J. (2017). "Project delivery models - situational or fixed design?" Proc. 12th Int. Scientific and Technical Conf. on Computer Sciences and Information Technologies (CSIT), IEEE, pp. 202-206.

Kulkarni, A., Rybkowski, Z. K., Smith, J. (2012). "Cost Comparison of Collaborative and IPD-Like Project Delivery Methods Versus Competetive Non-collaborative Project Delivery Methods." Proc. 20th Ann. Conf. Int. Group for Lean Constr., San Diego, CA, USA.

Lichtig, W. A. (2005). "Sutter health: Developing a contracting model to support lean project delivery." Lean Construction Journal, 2(1), pp. 105-112.

Malvik, T., Johansen, A. (2020). "Delivery models - degree of freedom- Norwegian Case study."

Matthews, O., Howell, G. A. (2005). "Integrated project delivery an example of relational contracting." Lean Construction Journal, 2(1), pp. 46-61.

Matthews, O., Howell, G. A., Mitropoulos, P. (2003). "Aligning the lean organization: a contractual approach." Proc. 11th Ann. Conf. Int. Group for Lean Constr., Virginia, USA, pp. 462-473.

Melo, R., Granja, A.D., Ballard, G. (2013). "Collaboration to extend target costing to non-multiparty contracted projects: evidence from literature." Proc. 21st Ann. Conf. Int. Group for Lean Constr., Fortaleza, Brazil, pp. 1-10.

Merrow, E. W. (2011). Industrial megaprojects. Hoboken, NJ: Wiley, pp.

Mesa, H. A., Molenaar, K.R., Alarcón, L.F. (2019). "Comparative analysis between integrated project delivery and lean project delivery." International Journal of Project Management, 37(3), pp. 395-409. 
Miller, J. B., Garvin, M. J., Ibbs, C. W., Mahoney, S. E. (2000). "Toward a new paradigm: Simultaneous use of multiple project delivery methods." Journal of Management in Engineering, 16(3), pp. 58-67, doi.org/10.1061/(asce)0742-597x(2000)16:3(58)

Morris, P. (2013). "Reconstructing project management reprised: A knowledge perspective." Project Management Journal, 44(5), pp. 6-23.

Morris, P. W. (2002). "Science, objective knowledge and the theory of project management." Proc. Institution of Civil Engineers-Civil Engineering, Thomas Telford Ltd, pp. 82-90.

Muller, R. (2017). "Project governance", Routledge.

Neville, C. (2004). Introduction to research and research methods. University of Bradford, School of management.

Nye Veier (2020). “About NyeVeier.” www.nyeveier.no/en/about-us/ (20.01.2020, 2020).

Oliveira, W. A. d., De Muylder, C. F. (2012). "Value creation from organizational project management: a case study in a government agency." Journal of Information Systems and Technology Management (JISTEM), 9(3), pp. 497-514.

Pikas, E., Koskela, L., Treldal, N., Ballard, G., Liias, R. (2016). "Collaboration in Design-Justification, Characteristics and Related Concepts." Proc. 24th Ann. Conf. Int. Group for Lean Constr., Boston, Mass., USA, pp. 143-152.

Shenhar, A. J., Dvir, D. (2007). "Reinventing project management: the diamond approach to successful growth and innovation”, Harvard Business Review Press.

Statens Vegvesen (2020). "Road Development through Public Private Partnership (PPP)." www.vegvesen.no/en/professional/roads/Public+Private+Partnership+PPP (20.01.2020, 2020).

Sødal, A. H., Lædre, O., Svalestuen, F., Lohne, J. (2014). "Early Contractor Involvement:Advantages and Disadvantages for the Design Team." Proc. 22nd A Ann. Conf. Int. Group for Lean Constr., Oslo, Norway, pp. 519-531.

Thomsen, C., Darrington, J., Dunne, D., Lichtig, W. (2009a). Managing integrated project delivery. Construction Management Association of America (CMAA), McLean, VA, 105, pp.

Thomsen, C., Darrington, J., Dunne, D., Lichtig, W. (2009b). Managing integrated project delivery. Construction Management Association of America (CMAA), McLean, VA, www.leanconstruction.org, 1-104.

Tjora, A. (2012). Qualitative Research Methods in Practice. 2nd Edition.

Yin, R. K. (2009). Case study research: design and methods. 4th ed., Sage, Thousand Oaks, Calif. 